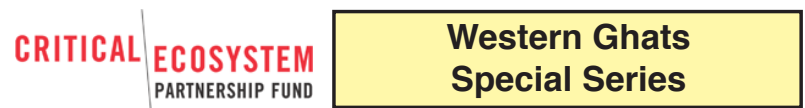

\title{
Metazoan community composition in tree hole aquatic habitats of Silent Valley National Park and New Amarambalam Reserve Forest of the Western Ghats, India
}

\author{
K.A. Nishadh ${ }^{1,2,3}$ \& K.S. Anoop Das ${ }^{1,2}$ \\ ${ }^{1}$ Centre for Conservation Ecology, Department of Zoology, M.E.S. Mampad College, Malappuram, Kerala 676542, India \\ ${ }^{2}$ Wildlife Research and Conservation Trust, Anupallavi, Chungathara P.O., Malappuram, Kerala 679334, India \\ ${ }^{3}$ Environmental Impact Assessment Division,Sálim Ali Center for Ornithology and Natural History, Anaikatty P.O, Coimbatore Tamil \\ Nadu 641108, India \\ Email: ${ }^{1}$ nishadhka@gmail.com, ${ }^{2}$ dasksa@gmail.com (corresponding author)
}

Phytotelmata, plant held aquatic habitats in tree holes are one of the important classes of aquatic ecosystems (Kitching 2000). These habitats are formed by the stagnation of rain water in cavities or depression of trees which make them one of the widely distributed and most abundant fresh water 'hanging aquaria' in forested woodlands (Kitching 1971). Well

Date of publication (online): 26 November 2012

Date of publication (print): 26 November 2012

ISSN 0974-7907 (online) | 0974-7893 (print)

Editor: K.G. Sivaramakrishnan

\section{Manuscript details:}

Ms \# 03197

Received 11 May 2011

Final received 13 August 2012

Finally accepted 03 October 2012

Citation: Nishadh, K.A. \& K.S.A. Das (2012). Metazoan community composition in tree hole aquatic habitats of Silent Valley National Park and New Amarambalam Reserve Forest of the Western Ghats, India. Journa of Threatened Taxa 4(14): 3312-3318.

Copyright: @ K.A. Nishadh \& K.S. Anoop Das 2012. Creative Commons Attribution 3.0 Unported License. JoTT allows unrestricted use of this article in any medium for non-profit purposes, reproduction and distribution by providing adequate credit to the authors and the source of publication.

Acknowledgements: The authors extend gratitude to Drs. V.S. Vijayan L. Vijayan, R. Sankaran, P.A. Azeez, T.V. Sajeev, G. Mathew, J.K Hill, P. Balakrishnan, P. Pramod, B. Acharya and P.R. Arun for their inspiring discussions during the project. Thanks to O.P. Abdurahiman, K. Seedikkoya, K.K. Abida and R. Dhanya for their support. We are indebted to the comments of the anonymous reviewers, which have enriched the manuscript. We thank the Department of Forests and Wildlife, Kerala, for permissions and support to conduct this study. We thank Idea Wild, USA for equipment grant. Funding was provided by the Critical Ecosystem Partnership Fund under the Western Ghats Small Grant through ATREE.

urn:Isid:zoobank.org:pub:F117E9D6-97EC-4A27-8F2F-F1E27B9E4C9F

OPEN ACCESS | FREE DOWNLOAD
Abstract: In a study of the metazoan community composition in tree hole aquatic habitat of a tropical rainforest, Silent Valley National Park, and the adjacent moist deciduous forest, New Amarambalam Reserve Forest, of the Western Ghats, 28 different species were recorded from 150 tree hole aquatic habitats with an average of 3-5 species per tree hole. Most of the recorded organisms (96.8\%) belong to Odonata (dragonflies and damselflies), Heteroptera (bugs), Diptera (flies), Coleoptera (beetles) and Trichoptera (caddisflies). The study reports the first record of toe-winged beetle larvae (Ptilodactylidae) in a tree hole aquatic habitat. The most significant observation is the prolific occurrence of trichopteran larvae as the second most abundant taxa in tree holes of Silent Valley National Park, and this stands as the first comprehensive record of the entire order in the habitat studied. The study upholds the importance of less explored microhabitats in the Western Ghats region in terms of sustaining unique community composition in the most delicate and extreme habitat conditions. It also puts forward important ecological research questions on biodiversity ecosystem functionality which could impart important lessons for managing and conserving the diminishing tropical evergreen forests which are significant for these unique habitats

Keywords: Ecosystem experimental tool, microcosm, phytotelmata, Scritidae, tree cavities, Trichoptera.

defined boundaries, confined size and extreme physiochemical conditions make these habitats colonized by specialized communities starting from autotrophic fungi to predaceous amphibians (Yanoviak 1999). It has attracted immense fascination from naturalists

This article forms part of a special series on the Western Ghats of India, disseminating the results of work supported by the Critical Ecosystem Partnership Fund (CEPF), a joint initiative of l'Agence Française de Développement, Conservation International, the Global Environment Facility, the Government of Japan, the MacArthur Foundation and the World Bank. A fundamental goal of CEPF is to ensure civil society is engaged in biodiversity conservation. Implementation of the CEPF investment program in the Western Ghats is led and coordinated by the Ashoka Trust for Research in Ecology and the Environment (ATREE). 
and community ecologists due to its canopy aquatic community, wide spatial and replicable distribution and extension of experimental studies on it (Kitching 2001). The physical barriers of a tree hole aquatic habitat sustains discrete communities in it that are mostly subsets of the larger forest ecosystems. Together with those features and methodological advantage for experimental studies makes them important experimental tools in ecology for studying processes and patterns occurring at the level of the community (Srivastava et al. 2004). Epidemiological importance of these habitats as major breeding grounds for disease spreading organisms such as mosquitos has further attracted the attention of these habitats to medical entomologists (Jenkins \& Carpenter 1946; Maguire 1971).

Extensive studies were carried out on these habitats in various parts of the world. But, the knowledge on the Indian tree hole aquatic habitat and its community composition is meager. In India, apart from the species listing and the natural history observations, only a few research efforts have addressed the ecological functionality and the responses of aquatic insects to specific ecosystems (Subramanian \& Sivaramakrishnan 2005). All other studies were of epidemiological concern (Rao et al. 1970; Nagpal \& Sharma 1985). The present study, the first of its kind in India, was carried out to assess the community composition in tree hole aquatic habitats.

\section{Materials and Methods}

The study was carried out in the Silent Valley National Park (SVNP) and New Amaramblam Reserve Forest (NARF) of the Western Ghats, Kerala from December 2009 to September 2010. This region is classified as west coast tropical wet evergreen forest, (Champion \& Seth 1968; $11^{0} 03^{\prime}-11^{0} 13^{\prime} N$ \& 76021'$\left.76^{\circ} 35^{\prime} \mathrm{E}\right)$ and forms a part of the Nilgiri Biosphere Reserve (Image 1). The forests of SVNP fall under the category of Malabar rainforest realm and the vegetation comprises mainly of the westcoast tropical evergreen and semievergreen forests (Udvardy 1975; Champion \& Seth 1968). The annual mean temperature in the SVNP ranges between $18^{\circ} \mathrm{C}$ and $23^{\circ} \mathrm{C}$ and mean annual precipitation ranges from $3200-5000 \mathrm{~mm}$ between the sections (Table 1). NARF $\left(11^{0} 26^{\prime}-11^{\circ} 9^{\prime} \mathrm{N} \& 75^{\circ} 45^{\prime}-\right.$ $\left.76^{0} 33^{\prime} \mathrm{E}\right)$ is a west coast tropical moist deciduous forest bordering northwest of SVNP. The annual mean temperature in this forest ranges from $21-38{ }^{\circ} \mathrm{C}$ and mean annual precipitation is $2397 \mathrm{~mm}$ (Das 2008).

\section{Survey Methods}

In SVNP tree holes were sampled from three regions of the park, namely, Sairandhri $(n=68)$, Poochipara $(n=34)$ and Walakkad $(n=35)$ whereas in NARF tree holes were mostly sampled from Panapuzha $(n=13)$.

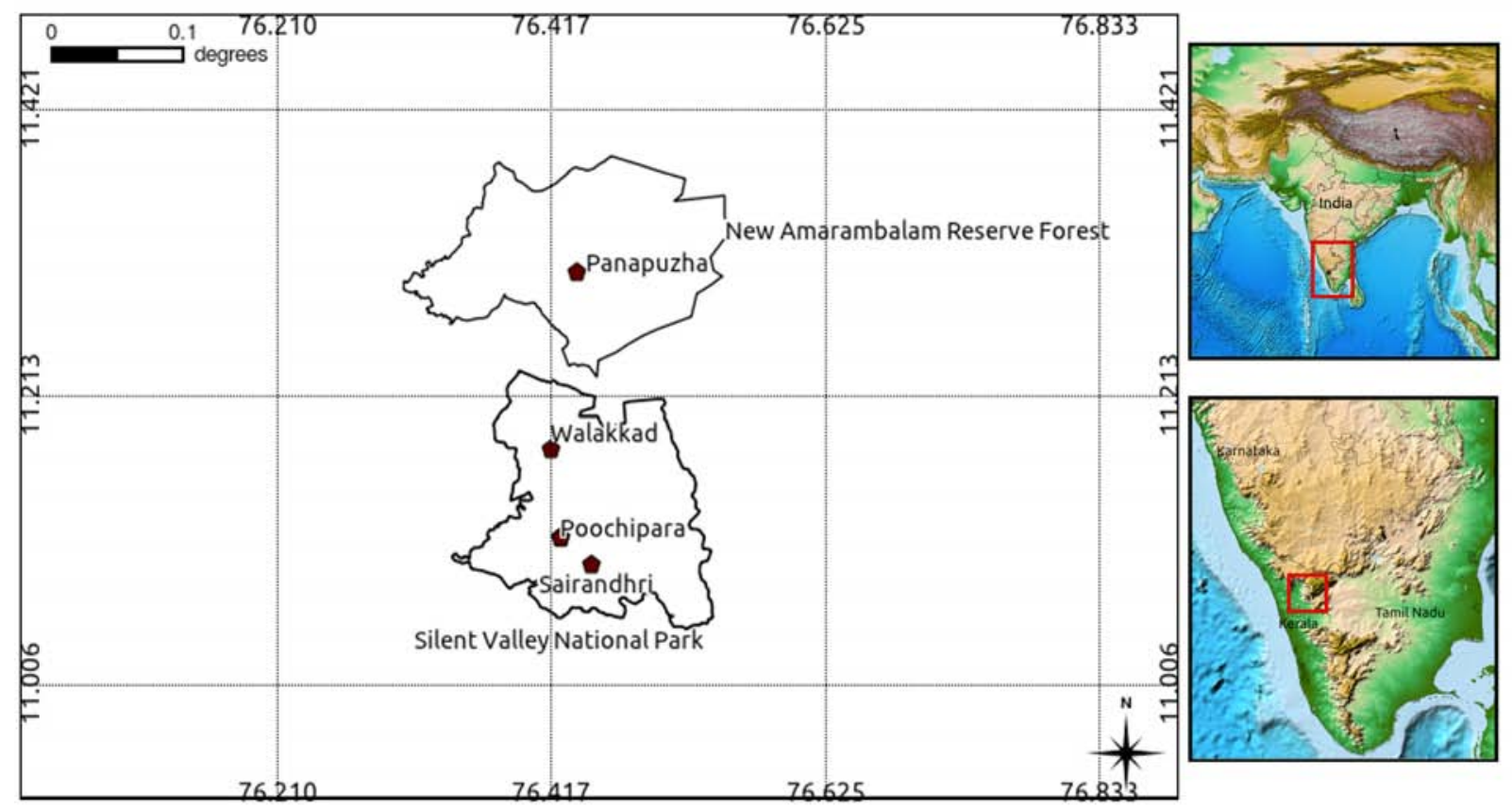

Image 1. The sampling locations in Silent Valley National Park and New Amarambalam Reserve Forest 
Table 1. Details of sampling locations in Silent Valley National Park and New Amarambalam Reserve Forest

\begin{tabular}{|l|l|l|l|}
\hline Place & Location & Altitude $(\mathrm{m})$ & Habitat matrix \\
\hline Sairandhri & $1^{0} 5^{\prime} 33.58^{\prime \prime} \mathrm{N} \& 76^{\circ} 26^{\prime} 44.61^{\prime \prime} \mathrm{E}$ & $1011-1056$ & West coast tropical wet evergreen Forest (logged) \\
\hline Poochipara & $1^{0} 6^{\prime} 40.81^{\prime \prime} \mathrm{N} \& 76^{\circ} 25^{\prime} 20.81^{\prime \prime} \mathrm{E}$ & $0962-0998$ & West coast tropical wet evergreen Forest (undisturbed) \\
\hline Walakkad & $11^{0} 10^{\prime} 89^{\prime \prime} \mathrm{N} \& 76^{\circ} 25^{\prime} 44^{\prime \prime} \mathrm{E}$ & $1160-1175$ & West coast tropical wet evergreen Forest (undisturbed) \\
\hline Panapuzha & $1^{0} 26^{\prime}-11^{\circ} 9^{\prime} \mathrm{N} \& 75^{\circ} 45^{\prime}-76^{\circ} 33^{\prime} \mathrm{E}$ & $0600-0675$ & West coast tropical moist deciduous forest \\
\hline
\end{tabular}

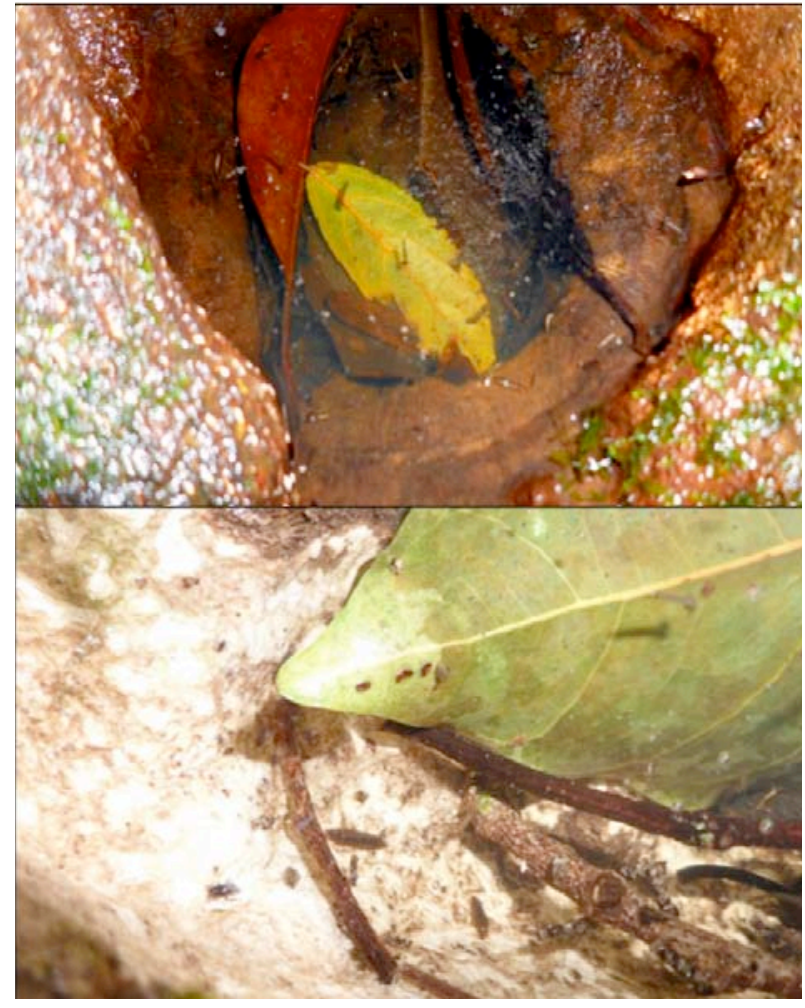

Image 2. Tree hole aquatic habitat and the typical communities residing in it, such as larvae of Trichoptera, Scritidae, Culicidae and a Hemiptera adult. @ K.S.A. Das

For every tree hole sampled, structural characteristics of the tree hole such as diameter were measured by taking two longest hole opening measurements perpendicular to each other (Sota 1998).

The variables such as depth, water volume and height of the tree hole from the ground, girth at breast height $(\mathrm{GBH})$ of the tree were also measured. Water from the tree hole was extracted by siphoning and the volume measured using a measuring cylinder. The content of the tree hole such as leaf litter and detritus were transferred to a tray and thoroughly checked for the presence of life forms (Image 2). Thorough checks were made with the aid of a flashlight for elusive organisms in cervices present in the tree hole. The water contents were then sieved with successive

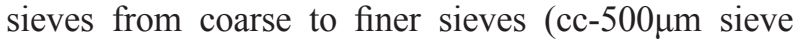
size) by holding in a plastic tray. The organisms were counted and morpho-species preserved in 5\% formalin (Yanoviak \& Fincke 2005). The collected specimens were sorted out and identified to possible taxonomic level of family/genus following Edmondson (1959), and Subramanian \& Sivaramkrishnan (2007).

\section{Results and Discussion}

The vegetation patterns in SVNP (Manilal 1988; Vajravelu 1990; Das 2008) and NARF (Sharma et al. 2002) are well documented. Most of the tree holes sampled in SVNP were from the tree species, Elaeocarpus tuberculatus, Syzygium cumini, Mesua ferrea,Holigarna arnottiana, Artocarpus heterophyllus, Dysoxylum malabaricum, Hopea parviflora, Myristica dactyloides and Acrocarpus fraxinifolius, whereas in NARF, the tree holes sampled belonged to Mangifera indica, Stereospermum chelnoids, Homonoia riparia, Tetramales nudiflora and Albizia lebbeck. A majority of the tree holes were of the 'pan' type (80.4\%) which appeared as a depression in the trunk. The remaining tree holes were 'rot' type (19.6\%) wherein the tree holes were formed by wreckage in the tree. Altogether, 7505 individuals of metazoans were recorded from 150 tree hole aquatic habitats. Aquatic insects belonging to the orders Coleoptera (beetles), Diptera (flies), Trichoptera (caddisflies), Heteroptera (bugs), and Odonata (dragonflies and damselflies) together comprised $96.8 \%$ of the entire collection (Table 2; Image 3 ). The remaining 3.2\% were the representatives of the taxa from Dermaptera, Annelida, Collembola, Gastropoda, Diplopoda, Geckonidae (Reptilia) and Anura (Amphibia). Larvae of marsh beetles (Scritidae) were the most abundant taxa, which occurred in $83.3 \%$ of all the tree holes sampled with an average abundance of $28.5 \pm 56.6$ individuals per tree hole at Sairandhri, $27.9 \pm 42.6$ at Poochipara, $20.08 \pm 20$ at Walakkad and $10.84 \pm 13.13$ at Panapuzha. It was followed by larvae of Trichoptera (62.6\%) with the highest abundance 
Table 2. Macro fauna in the tree hole aquatic habitat of Silent Valley National Park and New Amaramblam Reserve Forest. Values are mean number of individual taxa per tree hole. Percentage tree hole occupied by particular taxon is in parenthesis.

\begin{tabular}{|c|c|c|c|c|c|}
\hline \multirow[b]{2}{*}{ Sno } & \multirow[b]{2}{*}{ Phylum } & \multicolumn{3}{|c|}{ SVNP } & \multirow{2}{*}{$\begin{array}{c}\text { NARF } \\
\begin{array}{c}\text { Panapuzha } \\
(n=13)\end{array}\end{array}$} \\
\hline & & $\begin{array}{l}\text { Sairandhri } \\
\quad(n=68)\end{array}$ & $\begin{array}{l}\text { Poochipara } \\
(n=34)\end{array}$ & $\begin{array}{c}\text { Walakkad } \\
(n=35)\end{array}$ & \\
\hline 1 & Nematoda & - & - & $0.06(2.86)$ & - \\
\hline 2 & Annelida: Oligochaeta & $0.07(7.35)$ & $0.79(11.76)$ & $0.74(20.00)$ & - \\
\hline 3 & Arthropoda: Malacostraca: Oniscidea & - & - & $0.24(11.43)$ & - \\
\hline 4 & Decapoda: Gecarcinucidae & $0.03(2.94)$ & - & - & - \\
\hline 5 & Arachnida: Araneae & $0.09(8.82)$ & - & $0.41(17.14)$ & - \\
\hline 6 & Entognatha: Collembola & - & - & $0.26(14.29)$ & - \\
\hline 7 & Insecta: Odonata: Anisoptera: Libellulidae & $0.12(8.82)$ & $0.12(11.76)$ & - & $23.07(0.23)$ \\
\hline 8 & Hemiptera & $1.76(16.18)$ & $0.18(8.82)$ & $0.06(2.86)$ & $15.38(0.46)$ \\
\hline 9 & Diptera: Tipulidae: Tipulinae & $1.13(41.18)$ & $1.59(35.29)$ & $1.50(45.71)$ & $46.15(1.23)$ \\
\hline 10 & Tipulidae sp. & $0.43(22.06)$ & $1.12(17.65)$ & $0.24(14.29)$ & $23.07(0.46)$ \\
\hline 11 & Culicidae: Toxoyrinchites sp. & $0.15(8.82)$ & $0.06(2.94)$ & $0.09(8.57)$ & $30.76(0.61)$ \\
\hline 12 & Culex sp. & $6.85(33.82)$ & $1.65(23.53)$ & $0.97(28.57)$ & $23.07(1.46)$ \\
\hline 13 & Aedes sp. & $1.94(11.76)$ & $1.50(17.65)$ & $3.12(20.00)$ & $23.07(1)$ \\
\hline 14 & Chironomidae & $0.60(20.59)$ & $3.06(41.18)$ & $0.18(5.71)$ & $23.07(0.38)$ \\
\hline 15 & Ceratopogonidae & $0.07(2.94)$ & $0.24(11.76)$ & $0.09(8.57)$ & - \\
\hline 16 & Syrphidae: Eristalis sp. & $0.03(2.94)$ & - & $0.29(11.43)$ & - \\
\hline 17 & Coleoptera: Dytiscidae: Agabus sp. & $0.04(1.47)$ & $0.03(2.94)$ & $0.27(5.71)$ & $15.38(0.38)$ \\
\hline 18 & Hydrophilidae: Helochares sp. & $4.18(50.00)$ & $2.65(47.06)$ & $4.85(80.00)$ & - \\
\hline 19 & Scritidae & $28.51(80.88)$ & $27.94(94.12)$ & $20.88(88.57)$ & $84.61(10.84)$ \\
\hline 20 & Ptilodactylidae: Anchytarsus sp. & - & - & - & $23.07(1.3)$ \\
\hline 21 & Trichoptera & $17.32(79.41)$ & $7.97(64.71)$ & $2.09(60.00)$ & - \\
\hline 22 & Dermaptera & $0.01(1.47)$ & - & $0.03(2.86)$ & - \\
\hline 23 & Hymenoptera & - & $0.26(5.88)$ & - & $0.15(2.86)$ \\
\hline 24 & Blattaria & - & $0.03(2.94)$ & - & - \\
\hline 25 & Thysanoptera & $0.03(1.47)$ & $0.03(2.94)$ & - & - \\
\hline 26 & Mollusca: Gastropoda & - & - & $0.15(14.29)$ & $7.69(0.07)$ \\
\hline 27 & $\begin{array}{l}\text { Chordata: Amphibia: Anura: Microhylidae: } \\
\text { Ramanella sp. }\end{array}$ & $0.99(16.18)$ & $0.09(2.94)$ & $0.03(2.86)$ & $15.38(3.07)$ \\
\hline \multirow[t]{2}{*}{28} & $\begin{array}{l}\text { Reptilia: Squamata: Gekkonidae: } \\
\text { Cnemaspis sp. }\end{array}$ & $0.03(2.94)$ & $0.12(11.76)$ & - & - \\
\hline & Total taxa & 21 & 19 & 21 & 14 \\
\hline
\end{tabular}

of $17.3 \pm 42.6$ individuals at Sairandhri, $7.9 \pm 15.3$ individuals at Poochipara, $2.1 \pm 3.7$ individuals in Walakkad. Trichoptera was completely absent in the tree holes sampled at Panapuzha. With regard to richness of taxa, a typical tree hole in SVNP harbors $4 \pm 1.7$ taxa with a range of one to 11 different taxa per tree hole whereas Panapuzha of NARF harbored $3.6 \pm 1.3$ taxa with a range of 1-6 different taxa per tree hole. Out of 16 aquatic insect taxa recorded, nine were Diptera, four Coleoptera and one each of Trichoptera, Heteroptera, and Odonata. About 13 taxa of aquatic insects present in the tree holes were in the larval stage while three taxa belonging to Hydrophilidae, Dytiscidae of Coleoptera and Heteroptera were in the adult stage.

The structural characteristics, community structure, number of taxa and their abundance as well as the number of predators and saprophages present in the tree holes are given in Table 3. The saprophages include Scirtidae and Tipulidae. Scirtidae which are commonly called marsh beetles is the most abundant and highly characteristic group of tree hole aquatic habitat in the study area. It uses its specialized mouth parts to shred the leaf litters and in turn largely facilitate the conversion of coarse particulate organic 


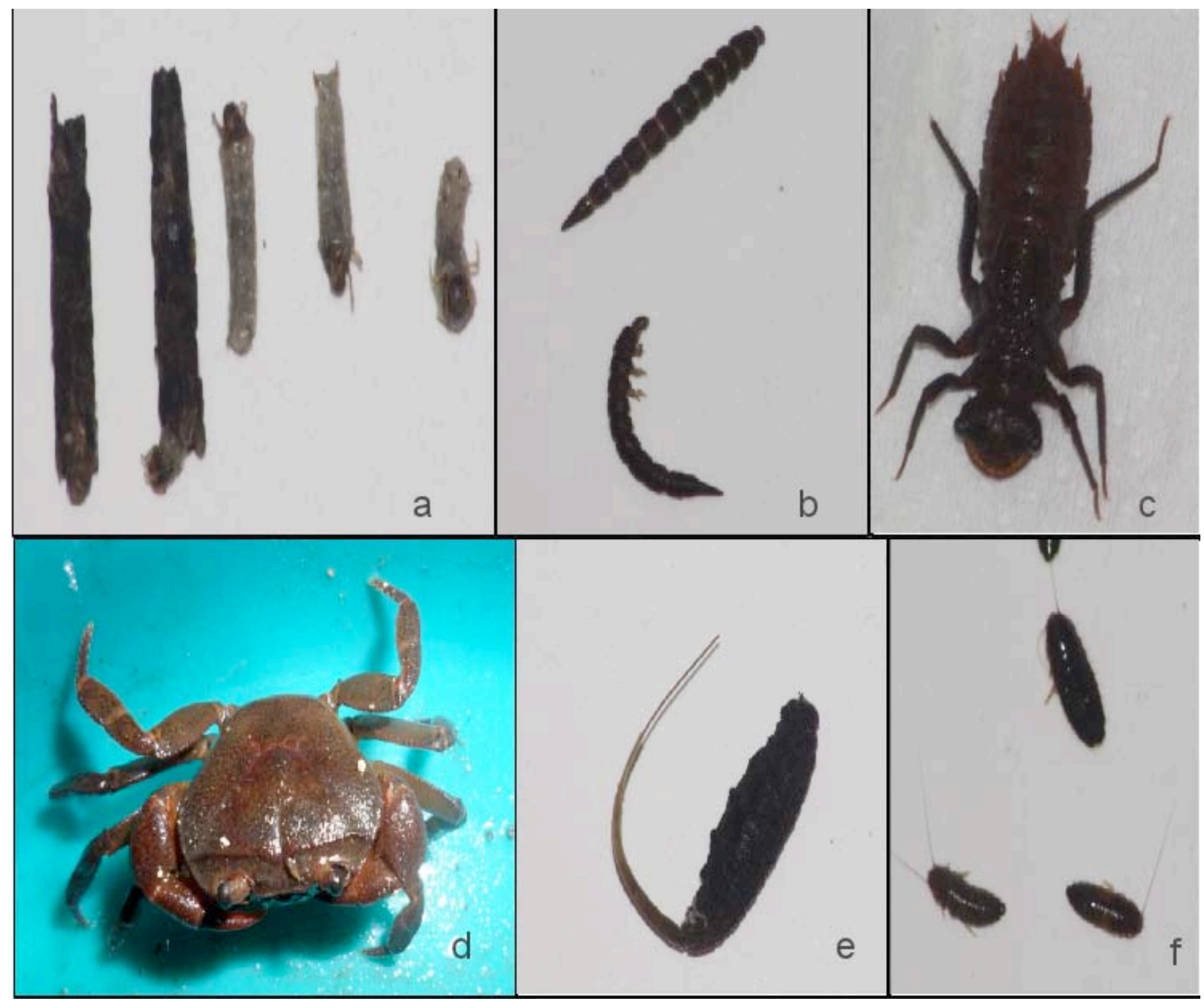

Image 3. Metazon communities in tree hole aquatic habitat. (๑) K.A. Nishadh

a - Trichoptera; b - Ptilodactylidae; c - Odonata nymph d - Decapoda; e - Syrphidae; f - Scritida

matter (CPOM) into fine particulate organic matter (FPOM). This species is considered to be an important community structure determining factor in tree hole aquatic habitats (Paradise \& Dunson 1997). There were about four prominent genera namely Cyphon, Princocyphon, Elodes, and Scrites observed in tree hole aquatic habitats, in which Scrites and Cyphon were the most speciose genera with about 50 species overall described from scritidae family from India (Ruta 2007). Tipulids (Diptera) act as large scale shredders and decomposers of leaf litter in tree hole aquatic habitats. The primitive structural characteristic and need to keep the respiratory plastron constantly in contact with air make them stay nearer the upper level of the water column in the tree hole aquatic habitat preferably in water-air interfaces. This designates them as one of the first processors and decomposers of fresh fallen leaf litter. Two groups of Tipulidae were observed from tree holes in the study area, one group with large structural characteristic larvae belongs to the subfamily Tipulinae and another relatively small size larval group which was unidentified. It was observed that physical characteristics such as depth, water volume of tree holes, and GBH of host tree were highly variable within sites and between sites. The predator aquatic insect taxa recorded to three taxa namely Toxyrinchites $\mathrm{sp}$. (Culcidae), Agabus sp. (Dytiscidae), and an anisopteran nymph of Odonata. Of these Anisoptera act as the top predator in the tree hole aquatic habitat (Kitching \& Orr 1996). The remaining taxa were saprophages grouped into macrosparophages, microsparphages and filter feeders based on feeding relation on coarse particulate organic matter, fine particulate organic matter and dissolved organic matter, respectively. 
Table 3. Tree hole habitat characteristics and community structure in various sites of Silent Valley National Park and New Amarambalam Reserve Forest

\begin{tabular}{|l|c|c|c|c|}
\hline Characters & $\begin{array}{c}\text { Sairandhri } \\
(\mathbf{n}=68)\end{array}$ & $\begin{array}{c}\text { Poochipara } \\
(\mathbf{n}=34)\end{array}$ & $\begin{array}{c}\text { Walakkad } \\
(\mathbf{n}=35)\end{array}$ \\
\hline Water volume, $\mathrm{ml}$ & $\begin{array}{c}1,439.29 \pm 3,291.69 \\
(100-7200)\end{array}$ & $752.88 \pm 953.72(50-3250)$ & $\begin{array}{c}528.85 \pm 1,718.75 \\
(20-10000) \\
(\mathbf{n}=13)\end{array}$ & $\begin{array}{c}\text { Panapuzha } \\
(50-6670)\end{array}$ \\
\hline Depth, cm & $10.69 \pm 10.48(3-74)$ & $17.30 \pm 34.82(2-150)$ & $99 \pm 7.53(3-34)$ & $19.69 \pm 19.14(2-70)$ \\
\hline $\begin{array}{l}\text { Height of the hole at rim, } \\
\text { cm }\end{array}$ & $84.12 \pm 62.32(16-148)$ & $89.67 \pm 70.80(5-300)$ & $62.15 \pm 102.29(5-440)$ \\
\hline GBH of tree, cm & $226.08 \pm 132.96(10-400)$ & $299.18 \pm 162.73(25-750)$ & $222.59 \pm 408.90(49-2502)$ & $320.54 \pm 467.66(51-1800)$ \\
\hline No. of taxa per tree hole & $4.04 \pm 1.71(1-9)$ & $4.18 \pm 1.45(2-8)$ & $4.59 \pm 1.79(2-11)$ & $3.62 \pm 1.39(1-6)$ \\
\hline $\begin{array}{l}\text { Abundance of taxa per } \\
\text { tree hole }\end{array}$ & $64.28 \pm 95.24(1-501)$ & $49.41 \pm 58.17(2-281)$ & $36.44 \pm 31.26(3-152)$ & $21.69 \pm 20.55(3-77)$ \\
\hline No. of predatory insects & $0.16 \pm 0.37(0-1)$ & $0.18 \pm 0.39(0-1)$ & $0.12 \pm 0.33(0-1)$ & $0.69 \pm 0.75(0-2)$ \\
\hline No. of saprophage insects & $3.88 \pm 1.58(1-9)$ & $4.00 \pm 1.41(2-7)$ & $4.47 \pm 1.78(2-11)$ & $2.92 \pm 1.04(1-4)$ \\
\hline
\end{tabular}

Values are mean+SD, and ranges in parenthesis.

Community composition was more similar within the tree hole aquatic habitats of SVNP and highly variable between SVNP and NARF (Table 3). Interestingly, aquatic insect taxa such as Trichoptera, Syraphidae and Ceratopoginidae were completely absent from NARF and the coleopteran group Ptilodactylidae was absent from SVNP tree holes. The feeding relationship of a community is mainly organized based on detritus food web in which the saprophage group were most represented in terms of abundance and taxa richness.

A notable record in the present study is the prolific occurrence of order Trichoptera (caddisflies) as the second most abundant group in tree hole aquatic habitats of the study area. Two former records on this order's occurrence in tree hole aquatic habitat suggest its rare colonization in the habitat (Barnard 1978; Greeney 2001; Taylor \& Ewers 2003). They are case makers and microsaprophages in nature, mostly seen as browsing on freshly fallen leaf litters. Toe-winged beetle larvae (Ptilodactylidae) were recorded only from tree holes of NARF and this record is considered to be the first record of this family in tree hole aquatic habitats studied elsewhere (Kitching 2000; Greeney 2001). The larval stage Anchytarsus sp. (Ptilodactylidae) was recorded, their larval stage lasts up to three years. They are macrosaprophagic in nature (Lesage \& Harper 1976).

One family Velidae of Hemiptera was reported from tree hole aquatic habitats (Yanoviak 1999). In the study area Hemipetra was represented by the family Gerridae. These organisms are amphibious in nature, so most of the time they were seen skating over the water surface and when disturbed sheltered in the tree bark cervices. They prefer tree holes with ample light availability and feed on prey available near the water surface, such as spiders and small insects. The report on this family in water-filled bamboo internodes documented its predacious and territorial behavior compared to other individuals (Kitching 2000). Dytiscidae and Hydrophilidae of the order Coleoptera were well represented in tree holes of SVNP. Genus Agabus (Dytiscidae) is a voracious predator both in the adult and larval life stages and is considered as one of the potential biocontrol agents for mosquito vectors. The swiftness in mobility and predation makes them one of the imperative top community structure determinants in tree hole aquatic habitats (Kitching 2000). In the adult stage Hydrophilidae act as scavengers and are mostly seen browsing on leaf litters. These beetles normally spend their larval stage in damp areas near water sources and at this stage they are carnivorous and cannibalistic (Edmondson 1959). Dragonfly (Odonata: Anisoptera) larvae occurring in tree hole aquatic habitats act as top predators. The presence of spoonshaped extensible labia in libellulid dragonflies makes them most adaptable predators in aquatic habitats.

The present study lists many species that were not previously recorded from the region. The interaction of evolutionary radiation and climate change over a time scale of a few million years explains why the moist forests of the world are so highly diverse. Periods of expansion and contraction of the forest, together with processes of speciation occurring within isolated patches, have been described as a 'species-pump' 
mechanism (Ananthakrishnan \& Sivaramakrishnan (2008). This is a valid explanation accounting for the increased speciosity and complexity of organisms in food webs in tree holes from tropical rainforests when compared with subtropical or temperate forests (Kitching 2000). Future studies should be designed to unravel the intricacies of "processing chain commensalisms" in tree holes (Ananthakrishnan \& Sivaramakrishnan 2008). Further research is needed, both to elucidate the ecology of aquatic insects in the tree holes, and to evaluate the impact of diverse predators on tropical populations.

\section{REFERENCES}

Ananthakrishnan, T.N. \& K.G. Sivaramakrishnan (2008). Ecological Entomology: Insect Life in Odd Environments. Scientific Publishers, India, 142pp.

Barnard, P.C. (1978). An unusual habitat for the caddis larva Glyphotaelius pellucidus (Retzuis) (Trichoptera: Limnephilidae). Entomological Gazette 29: 224.

Champion, H.G. \& S.K. Seth (1968). A Revised Survey of the Forest Types of India. Government of India Press, New Delhi, 404pp.

Das, K.S.A. (2008). Bird community structure along the altitudinal gradient in Silent Valley National Park, Western Ghats, India. $\mathrm{PhD}$ Thesis. Bharathiar University, Coimbatore.

Edmondson, W.T. (1959). Fresh Water Biology, John Wiley and Sons, New York, $\mathrm{xx}+1248 \mathrm{pp}$.

Greeney, H.F. (2001). The insects of plant-held waters: a review and bibliography. Journal of Tropical Ecology 17: 241-260.

Jenkins, D.W. \& S.J. Carpenter (1946). Ecology of the tree hole breeding mosquitoes of nearctic North America. Ecological Monographs 16: 31-47.

Kitching, R.L. (1971). An ecological study of water-filled treeholes and their position in the woodland ecosystem. Journal of Animal Ecology 40: 281-302.

Kitching, R.L. (2000). Food Webs and Container Habitats: The Natural History and Ecology of Phytotelmata. Cambridge University Press, Cambridge, xiii +431.

Kitching, R.L. (2001). Foodwebs in phytotelmata: bottom-up and top-down explanations. Annual Review of Entomology 46: 729-60.

Kitching, R.L. \& A.G. Orr (1996). The food web from water filled treeholes in Kuala Belalong, Brunei. The Raffles Bulletin of Zoology 44(2): 405-413.

Lesage, L. \& P.P. Harper (1976). Notes on the life history of the Toed-winged Beetle Anchytarsus Bicolor (Melsheimer) (Coleoptera: Ptilodactylidae). The Coleopterists Bulletin 30(3): 233-238.

Maguire, B.J. (1971). Phytotelmata: Biota and community structure determination in plant-held waters. Annual Review of Ecology and Systematics 2: 439-464.
Manilal, K.S (1988). Flora of Silent Valley: Tropical Rain Forests of India. The Mathrubhumi Press, Calicut, 398pp.

Nagpal, B.N. \& V.P. Sharma (1985). Tree hole breeding and resting of mosquitoes in Orissa. Indian Journal of Malariology 22: 115-117.

Paradise, C. J., \& W.A. Dunson (1997). Insect species interactions and resource effects in treeholes: are Helodid Beetles bottom-up facilitators of midge populations? Oecologia 109: 303-312.

Ruta, R. (2007). Scirtidae of India and Sri Lanka-Part 1. The chlorizans-group of Cyphon Paykull, 1799 (Insecta: Coleoptera). Genus (Wroclaw) 17(2): 323-340.

Rao, T.R., K.N. Pannicker \& R. Reuben (1970). Tree-Hole breeding of Aedes aegypti in southern India: a preliminary report. Bulletin of World Health Organization 42(2): 333334.

Sharma, J.K., K.K.N. Nair, G. Mathew, K.K. Ramachandran, E.A. Jayson, K. Mohanadas, U.N. Nandakumar \& P.V. Nair (2002). Studies on the Biodiversity of New Amarambalam Reserved Forest of Nilgiri Biosphere Reserve, KFRI Research Report No.247, Peechi, 2002.

Sota, T (1998). Microhabitat size distribution affects local difference in community structure: metazoan communities in treeholes. Research in Population Ecology 40: 249-255.

Srivastava D.S., J. Kolasa, J. Bengtsson, A. Gonzalez, S. P. Lawler, T.E. Miller, P. Munguia, T. Romanuk, D. C. Schneider \& M.K. Trzcinski (2004). Are natural microcosms useful model systems for ecology? Trends in Ecology and Evolution 19: 379-384.

Subramanian, K.A. \& K.G. Sivaramakrishnan (2005). Habitat and microhabitat distribution of stream insect communities of the Western Ghats. Current Science 89(6): 976-987.

Subramanian, K.A. \& K.G. Sivaramkrishnan (2007). Aquatic Insects of India - A Field Guide. Ashoka Trust for Research in Ecology and Environment (ATREE), Bangalore, India, $62 \mathrm{pp}$.

Taylor, R.C. \& R.M. Ewers (2003). The invertebrate fauna inhabiting tree holes in a Red Beech (Nothofagus fusca) tree. The Weta 27: 24-27.

Udvardy, M.D. (1975). A Classification of The Biogeographical Provinces of The World. International Union of Conservation of Nature and Natural Resources, Switzerland, 50pp.

Vajravelu, E. (1990). Flora of Palghat, including Silent Valley National Park, Kerala. Botanical Survey of India, Culcutta, XIV+646pp.

Yanoviak, S.P. (1999). Community structure in water-filled tree holes of Panama: effects of hole height and size. Selbyana 20: 106-115.

Yanoviak, S. P. (2001). The macrofauna of water-filled tree holes on Barro Colarado Island, Panama. Biotropica 33(1): 110-120.

Yanoviak, S.P. \& O.M. Fincke (2005). Sampling methods for water filled tree holes and their artificial analogues, pp. 168-185. In: Simon, R.L. (ed.). Insect Sampling in Forest Ecosystems. Blackwell Publishing, Oxford, 320pp. 